\title{
S100 is preferentially distributed in myelin-forming Schwann cells
}

\author{
M. MATA, D. ALESSI and D. J. FINK \\ Neurology Research Laboratory, VA Medical Center and Department of Neurology, University of Michigan, Ann Arbor, MI, USA
}

Received 9 June 1989; revised 4 September and 14 November 1989; accepted 24 November 1989

\begin{abstract}
Summary
In order to elucidate the role of $\mathrm{S} 100$ protein in vivo we used postembedding electron microscopical immunocytochemistry with commercially available antibodies to $\$ 100$, and secondary antibodies conjugated to colloidal gold to determine the distribution of $S 100$ protein in the sciatic nerve and the cervical sympathetic trunk of the rat. We found that S100 immunoreactivity in Schwann cells was differentially distributed. The amount of S100 immunoreactivity in myelinated fibres appeared to correlate directly with the thickness of the myelin sheath formed by the Schwann cell. Unmyelinated fibres were identical to the small myelinated fibres in S100 immunoreactivity. Within the Schwann cells, the immunoreactivity was seen in the nucleus and in the perikaryal cytoplasm, as well as in the Schmidt-Lanterman clefts and in the paranodal loops at the node of Ranvier, but not in the myelin itself. Using these antibodies we did not see reproducible or convincing intra-axonal immunoreactivity in normal nerve.

These results suggest that in Schwann cells S100 expression may be related to axon diameter and degree of myelination. Future studies of $\$ 100$ expression in development or in response to injury may clarify the role of S100 in Schwann cell biology.
\end{abstract}

\section{Introduction}

The $\$ 100$ proteins were initially characterized as a group of abundant low molecular weight (10-12 kDa) acidic proteins highly enriched in nervous tissue (Moore, 1965, 1982). The S100 protein is a dimer made up of two subunits, alpha and beta, which are closely related peptides with a $58 \%$ homology in amino acid sequences (Isobe \& Okuyama, 1981; Isobe et al., 1981). Immunocytochemical studies have shown that $S 100$ is found predominantly in glia in the CNS (Matus \& Mughal, 1975; Ludwin et al., 1976; Cocchia, 1981) and in Schwann cells in the peripheral nervous system (PNS) (Cocchia \& Michetti, 1981; Stefansson et al., 1982). More recently it has been demonstrated that $S 100 \mathrm{a}_{0}$, a dimer made up of 2 alpha subunits and which accounts for $<5 \%$ of total 5100 , is localized principally in neurons, while alpha/beta and beta/beta dimers (S100a and S100b, respectively) are located in glia (Isobe et al., 1984). This differential localization may account for some early reports of S100 immunoreactivity in neurons (Haglid et al., 1974; Hansson et al., 1975).

The $\$ 100$ proteins are members of a large family of calcium-binding proteins of the $\mathrm{EF}$ hand structure (Donato, 1986; Kligman \& Hilt, 1988), and detailed studies of their calcium-binding properties and calcium-induced conformational changes have been completed (Baudier, 1988). Because of its similarity to calmodulin, there has been speculation that S100 may play a role in transducing the effects of alterations in intracellular calcium concentration.

In vitro, S100 has been demonstrated to mediate calcium-dependent microtubule dissociation (Baudier et al., 1982; Donato, 1988) and calcium-dependent inhibition of tau phosphorylation (Baudier \& Cole, 1988). S100b has been shown to specifically inhibit the phosphorylation of pp80, a major protein kinase $C$ substrate (Kligman \& Patel, 1986). But the role of S100 in the nervous system in vivo has not been defined yet. $\mathrm{S} 100$ is present in the rat nervous system in small amounts at birth and increases rapidly during the first month of life (Herschman et al., 1971; Stewart \& Urban, 1972; Hyden \& Ronnback, 1975; Donato, 1976; Haglid et al., 1977), suggesting that it may be involved in vivo in nervous system development.

In order to gain further knowledge of the role of S100 protein in the PNS, we undertook this electron microscopical histochemical study of S100 localization. 


\section{Materials and methods}

\section{Immunocytochemistry}

Male Sprague-Dawley rats, 200-250 g, were used in these studies. The animals were perfused through the heart with $100 \mathrm{~mm}$ phosphate buffer followed by a mixture of $0.5-2.5 \%$ glutaraldehyde and $4 \%$ paraformaldehyde in phosphate buffer. The sciatic nerve and the cervical sympathetic trunk were removed, cut into blocks, placed in the same fixative for an additional $2 \mathrm{~h}$, and then embedded in LR White (Polysciences).

Ultrathin sections were exposed to affinity purified polyclonal antiserum to $S 100$ (Dako) diluted 1:300 to $1: 1000$ for $2 \mathrm{~h}$ at room temperature, followed by goat anti-rabbit IgG bound to 15 or $20 \mathrm{~nm}$ colloidal gold (E-Y Laboratories) for $1 \mathrm{~h}$ at room temperature. The grids were stained for $20 \mathrm{~min}$ with uranyl acetate and examined in a JEOL 100-S electron microscope.

We performed two controls for the immunocytochemical reaction. The first control consisted of deletion of the primary antibody. The second control was reaction in an identical manner using preabsorbed primary antibody with $0.5 \mathrm{mg} \mathrm{ml}^{-1} \mathrm{~S} 100$ (Wako).

\section{Quantitative analysis of immunoreactivity}

In order to obtain a quantitative estimate of the relationship of gold particle density to fibre type, grids from three different but identically performed experiments were analysed. Each of the grids had been incubated with the primary antibody diluted 1:300 for $2 \mathrm{~h}$ followed by secondary antibody conjugated to $15 \mathrm{~nm}$ colloidal gold at $1: 8$ for $1 \mathrm{~h}$. The grids were photographed and printed at $\times 15000$ magnification on $20 \times 25 \mathrm{~cm}$ paper. The number of gold particles in each Schwann cell was counted, the myelin thickness measured directly on the photograph, and the area of the Schwann cell computed from the photograph using a computerized digitizer pad (Sigma Scan, Jandel Scientific). All the Schwann cells with visible perikaryal cytoplasm at the level of the nucleus $(n=149)$ were analysed. These included 15 unmyelinated fibres, 53 small myelinated fibres (myelin thickness $0.27 \pm 0.09 \mu \mathrm{m}$ ), 24 medium-size myelinated fibres $(0.63 \pm 0.19 \mu \mathrm{m})$, and 57 large myelinated fibres $(1.14 \pm 0.22 \mu \mathrm{m})$. A total of 92601 gold particles were counted. The density of gold particles (number of particles per $10^{9} \mu \mathrm{m}^{2}$ ) was plotted against myelin thickness and the Pearson correlation computed (SYSTAT).

\section{Western blot}

The specificity of the antiserum for 5100 in nerve was confirmed by Western blot. Sciatic nerve and cervical sympathetic trunk from similar animals were sonicated with a Polytron (Brinkmann) in $5 \mathrm{~mm}$ Tris, $5 \mathrm{~mm} \mathrm{NaCl}$ ( $\mathrm{pH}$ 7.3) on ice, centrifuged at $6300 \mathrm{~g}$ for $15 \mathrm{~min}$, and the resulting supernatant separated into pellet (membrane) and supernatant (soluble) fractions by centrifugation at $130000 \mathrm{~g}$ for $1 \mathrm{~h}$ in an Airfuge (Beckman). The pellet and supernatant fractions were resolved on a $17.5 \%$ SDS-polyacrylamide gel using the buffer system of Laemmli (1970) and transferred to nitrocellulose in Towbin buffer (Towbin et al., 1979). The blot was reacted with the primary antibody $(1: 300)$ followed by peroxidase-conjugated goat anti-rat $\operatorname{IgG}(1: 200$, Cappel), and developed with 4-chloro-1-naphthol as described by Siegel and co-workers (1986). A gel run in parallel was stained with Coomassie Blue.

\section{Results}

\section{Antibody characterization}

Western blot of the proteins from sciatic nerve demonstrated immunoreactive protein species only in the soluble, supernatant fraction. On these gels $\$ 100$ alpha and S100 beta were not distinguishable, nor were they distinguishable on 2D gel electrophoresis (not shown). Occasionally, minor immunoreactivity with high $\mathrm{M}_{\mathrm{R}}$ components was seen, but these bands were variable and appeared to account for less than $1 \%$ of the immunoreactive protein in nerve. The sciatic nerve showed a clear band of immunoreactivity (Fig. 1 , lane e) but the sample from the cervical sympathetic trunk shows very little immunoreactivity (Fig. 1, lane d).

\section{Localization of 5100 in sciatic nerve}

In agreement with previous studies, we found $S 100$ principally in Schwann cells. The immunoreactivity was seen diffusely in the nucleus and cytoplasm of
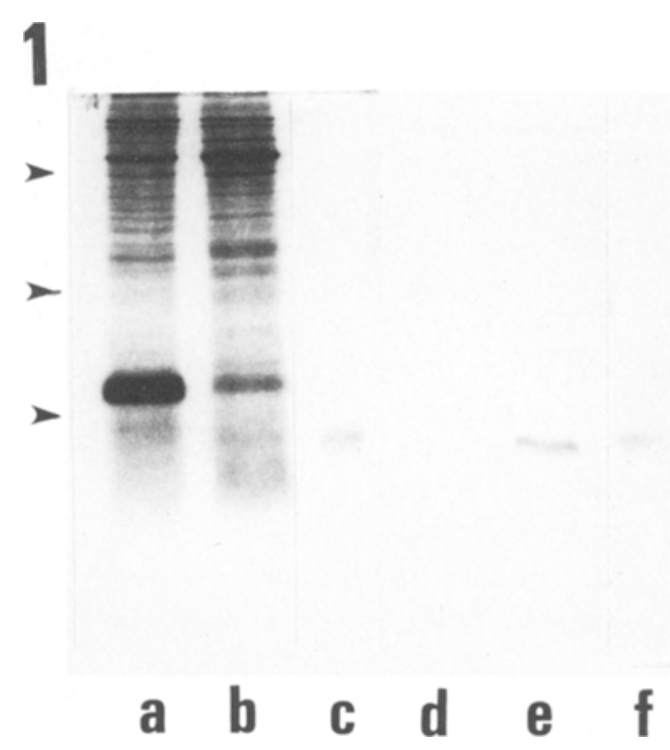

Fig. 1. $17.5 \%$ SDS gel stained with Coomassie Blue $(a-c)$ and Western blot of identical samples (d-f). Cervical sympathetic trunk ( $a$ and $d$ ), sciatic nerve (b and e), and S100 protein ( $c$ and $\mathrm{f}$ ). Molecular weight standards $45 \mathrm{~K}, 30 \mathrm{~K}$ and 14K (arrowheads). 


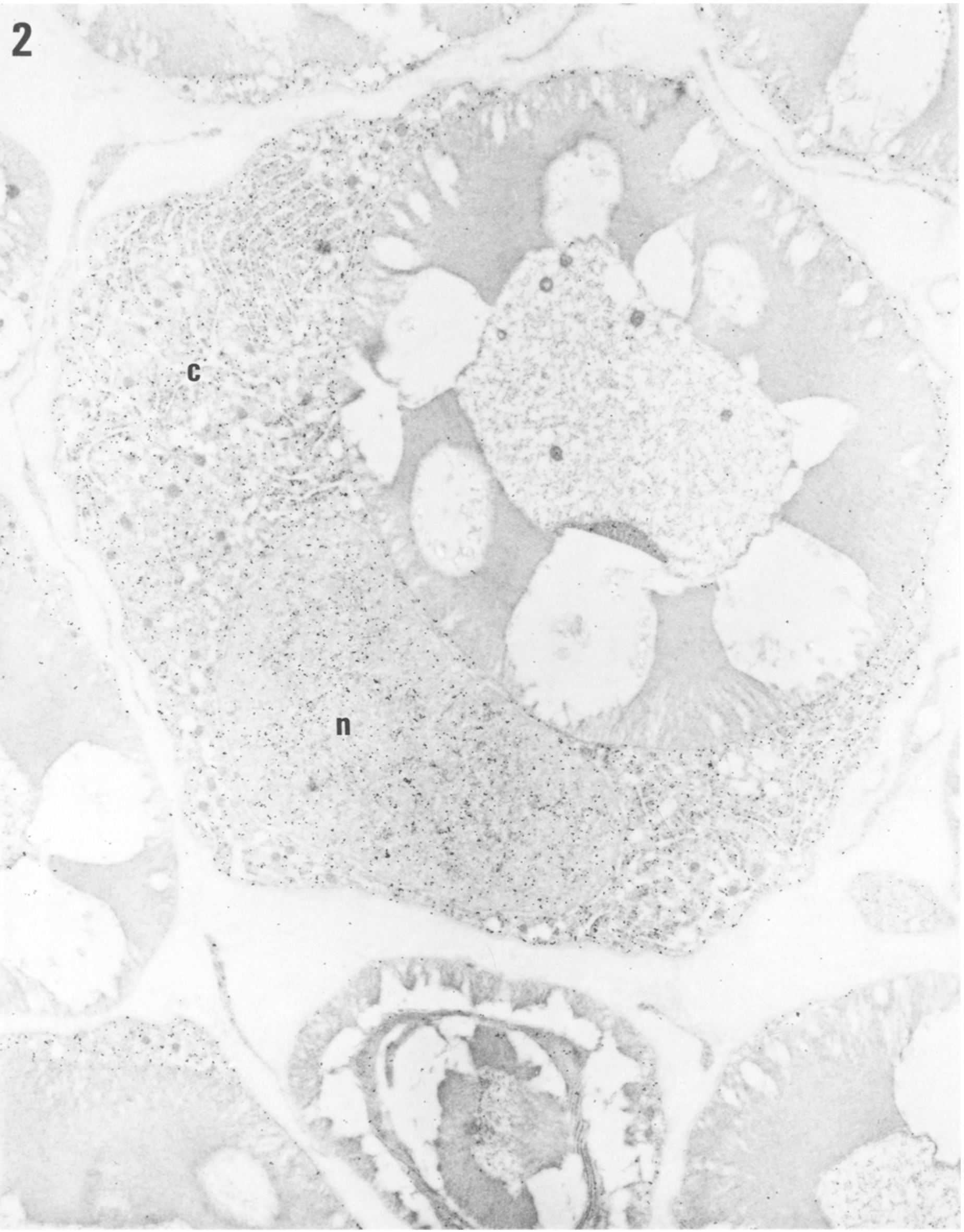

Fig. 2. Cross-section of a large myelinated axon from the sciatic nerve, demonstrating S100 immunoreactivity diffusely through the cytoplasm (c) and nucleus (n). Primary antibody 1:400. $\times 21600$. 


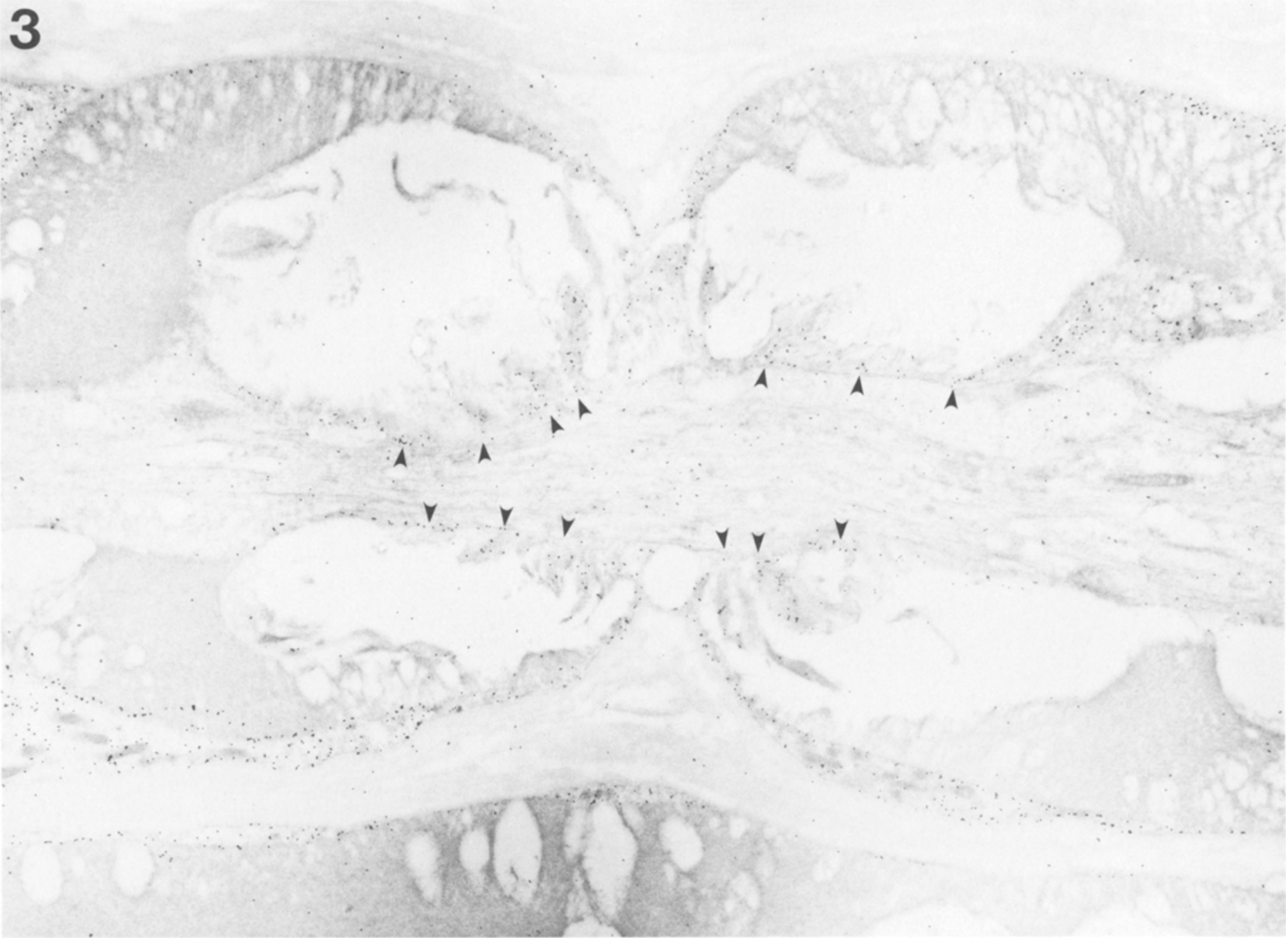

Fig. 3. Longitudinal section of sciatic nerve through a node of Ranvier demonstrating $\$ 100$ immunoreactivity in the paranodal loops of myelin (arrowheads). Primary antibody 1:300. $\times 16200$. 
these cells (Fig. 2), in the paranodal loops of myelin (Fig. 3) and along the Schmidt-Lanterman clefts (Fig. 4).

We found essentially no 5100 immunoreactivity within axons with any of the antibodies we used.

The most important finding was that $\mathrm{S} 100 \mathrm{immuno-}$ reactivity apperared to be much more prominent in the cytoplasm of myelin-forming Schwann cells than in those Schwann cells apposed to unmyelinated axons, and a greater density of $\mathbf{S 1 0 0}$ immunoreactivity was seen in the Schwann cells of large myelinated fibres than in the Schwann cells surrounding small myelinated fibres (Figs 4 and 5). This differential distribution of S100 immunoreactivity on single grids was seen independently of the dilution of the primary antibody and was independent of the concentration of glutaraldehyde used in fixation, although specimens processed in $2.5 \%$ glutaraldehyde (Fig. 5A) showed somewhat less immunoreactivity than those processed in $0.5 \%$ glutaraldehyde (Fig. $5 \mathrm{~B}$ ).

Controls performed with deletion of the primary antibody (Fig. 6A) or antibody preabsorbed with purified S100 protein (Fig. 6B) showed no colloidal gold deposition.

We also examined the cervical sympathetic trunk which contains principally unmyelinated, and a few small myelinated, fibres. The amount of $5100 \mathrm{im}-$ munoreactivity in Schwann cells of the cervical sympathetic trunk was low (Fig. 7), comparable to that seen in the Schwann cells of unmyelinated and small myelinated fibres in the sciatic nerve. This is in agreement with the electrophoretic and immunoblot data (Fig. 1).

\section{Quantitative analysis of immunoreactivity}

Although immunocytochemistry with colloidal gold is not strictly quantitative, the density of gold particles correlates with the distribution of the antigen in the section when other experimental parameters are held constant. Visual inspection described above suggested that the amount of immunoreactivity correlated with fibre type. In order to demonstrate this correlation, 149 fibres from three identicallyperformed experiments were analysed for the density of gold particles in Schwann cell cytoplasm, and the results plotted against myelin thickness as described in Materials and methods. The correlation, shown in Fig. 8 , is statistically significant $(\mathrm{R}=0.887, P<0.001)$. Unmyelinated fibres, not included in Fig. 8, were identical to the smallest myelinated fibres in gold particle density (data not shown).

\section{Discussion}

The major finding of this study is that S100 immunoreactivity is predominantly found in myelin-forming Schwann cells, and that the amount of $\$ 100$ immunoreactivity in the Schwann cell correlates with the thickness of the myelin sheath formed by that cell. Stefansson and co-workers (1982) have previously demonstrated, using light microscopical immunocytochemistry, that S100 is found in Schwann cells in both myelinated and unmyelinated peripheral nerves, but it is not possible to compare the relative amounts of $\$ 100$ immunoreactivity in the different Schwann cell populations in that study.

The differential distribution of $\mathrm{S} 100$ in cells forming myelin suggests that 5100 -mediated interactions may be involved in the process of forming or maintaining myelin. Data from in vitro studies suggest that glial cells in tissue culture express low levels of S100 immunoreactivity constitutively, but when cultured in the presence of neurons accumulate high levels of S100 (Holton \& Western, 1982, 1988). Other investigators have shown that Schwann cells in culture require axonal contact to form myelin (Bunge et al., 1980). The time course of expression of $S 100$ in developing rat nervous system broadly parallels the course of myelination, the amount of $\$ 100$ increasing rapidly during the first two months of life (Herschman et al., 1971; Stewart \& Urban, 1972; Hyden \& Ronnback, 1975; Donato, 1976; Haglid et al., 1977). However, a systematic study of the relationship of S100 expression to the time of myelination of specific tracts has not been performed.

Ultrastructural studies suggest that in adipocytes S100 may serve as one of the intracellular protein

Fig. 4. Cross-section of sciatic nerve demonstrating differential distribution of S100 immunoreactivity. Schwann cells surrounding unmyelinated fibres (asterisks) and small myelinated fibres (open arrow) contain less S100 immunoreactivity than adjacent Schwann cells surrounding large myelinated fibres. Immunoreactivity is also seen in the Schmidt-Lanterman cleft (solid arrow). No immunoreactivity is seen in fibroblasts (f). (A) Primary antibody 1:400. $\times 15000$. (B) Primary antibody $1: 400 . \times 14400$.

Fig. 5. Adjacent axons in cross-section of sciatic nerve (A) and ventral root (B), sectioned through the level of the Schwann cell nucleus, demonstrate the differential distribution of S100 immunoreactivity between the Schwann cell surrounding the large myelinated fibres and those surrounding small myelinated fibres. Cytoplasm (c), nucleus (n), small myelinated fibre (open arrow). (A) Primary antibody 1:700. $\times 15000$. (B) Primary antibody 1:700. $\times 16000$.

Fig. 6. Control sections. (A) Omission of the primary antibody. $\times 18000$. (B) S100 antibody (1:700) preabsorbed by $1.25 \mathrm{mg} \mathrm{ml}^{-1} \mathrm{~S} 100$ protein. $\times 15000$. 
4 A

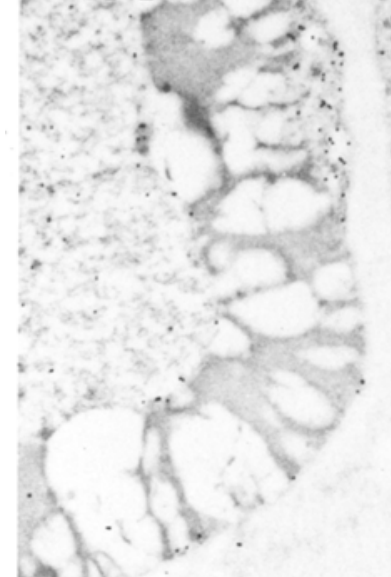

an.

7x)
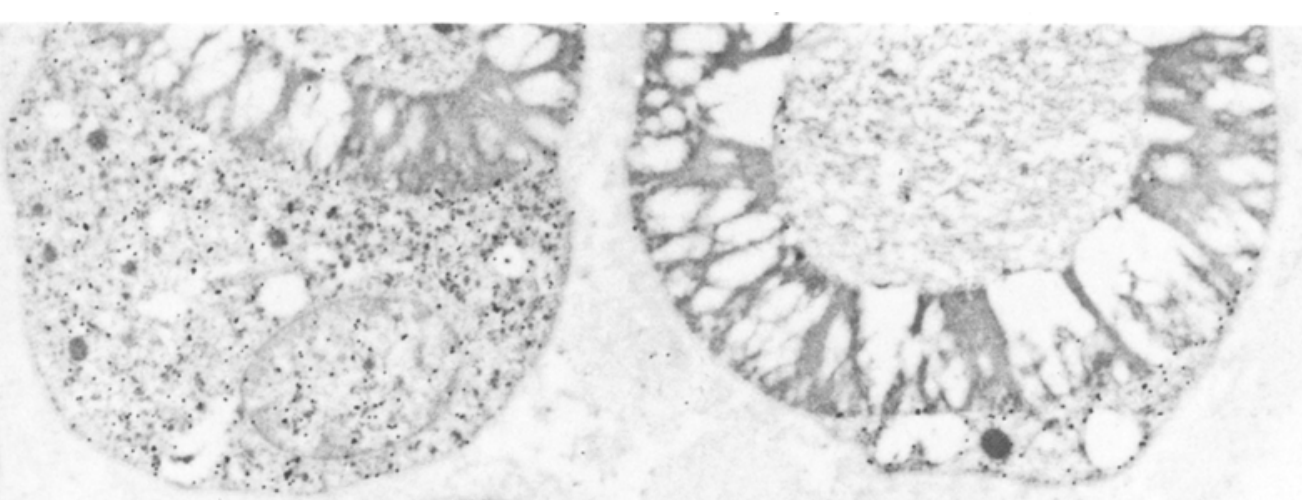

8
2
5
5
5
5
5

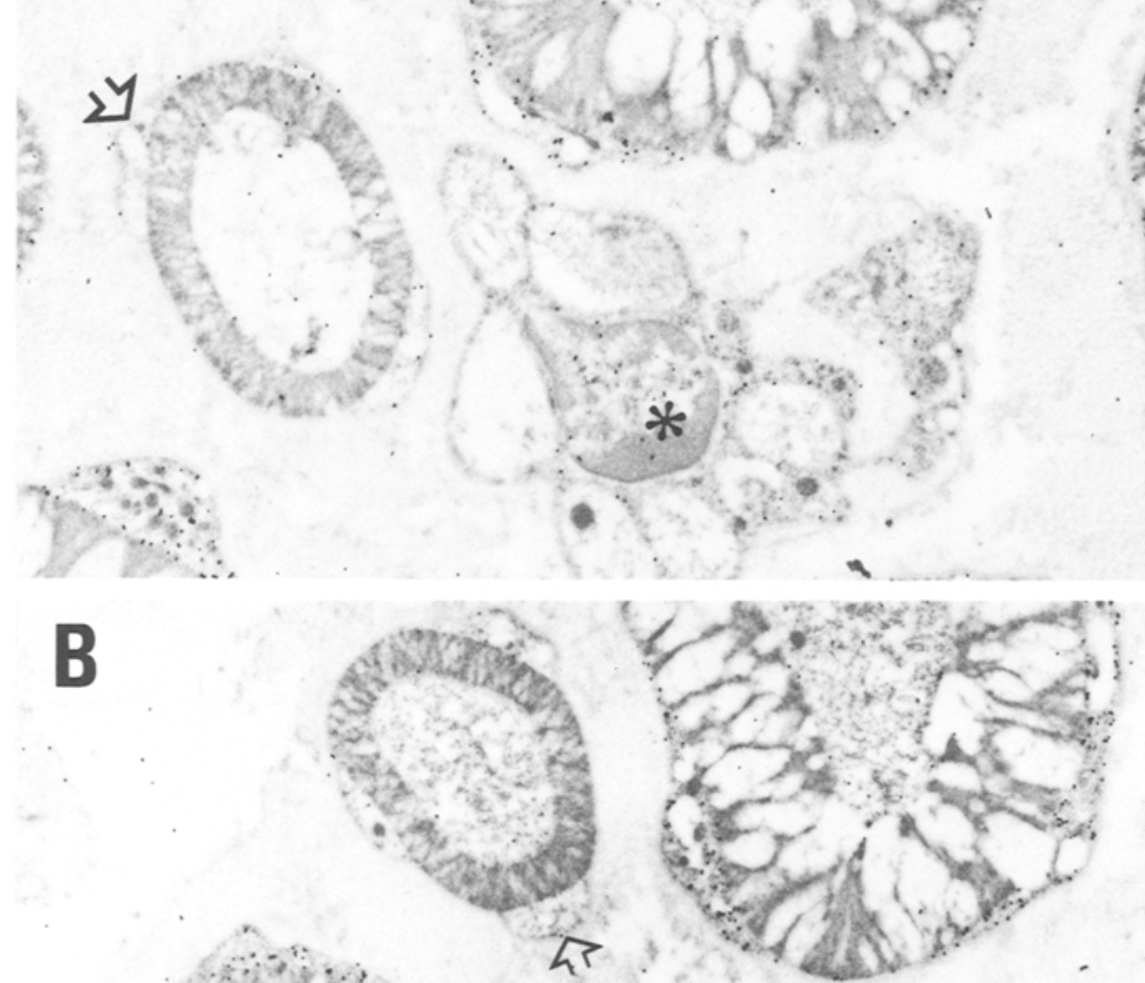

(1) 1125

$4 \times$

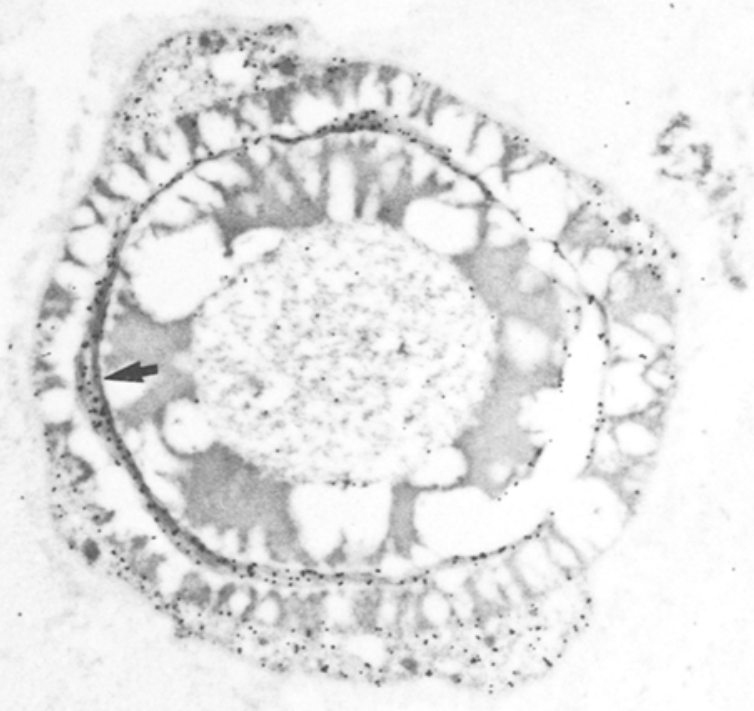

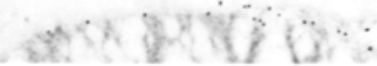

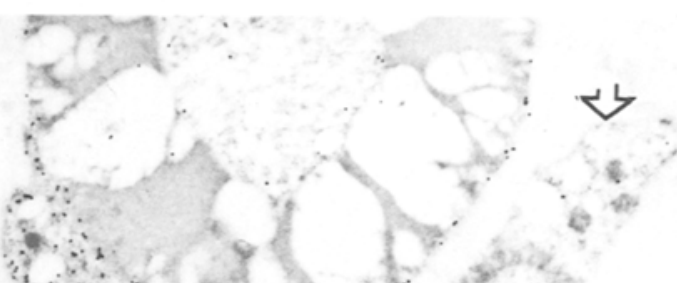

Sitis

$$
\text { a } 421,2
$$

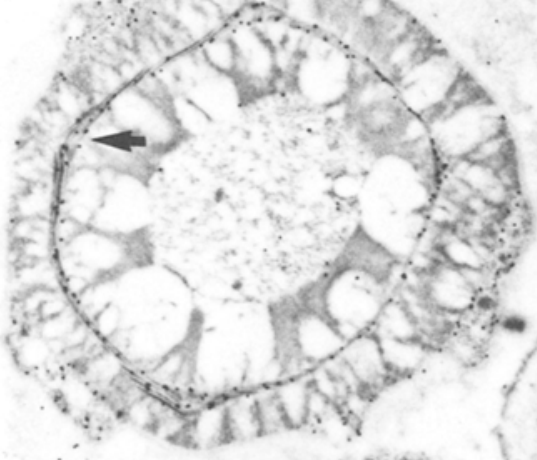

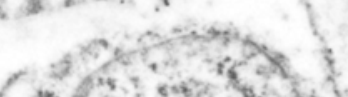

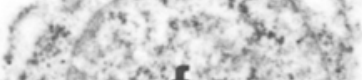

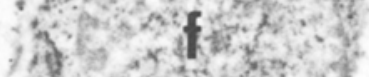

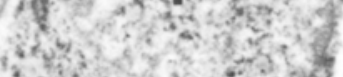

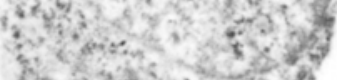
the the 4 .

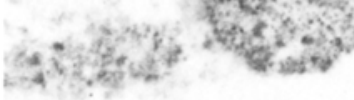
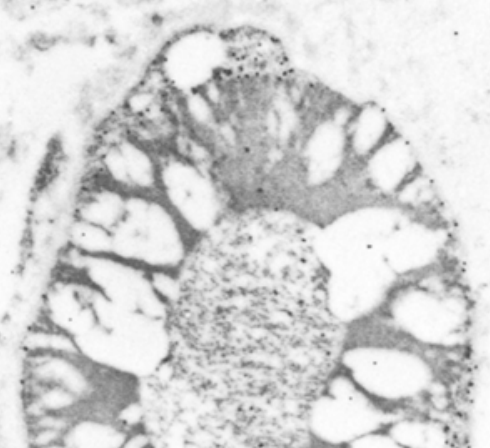

$\sin$ ?

Allortion
के

dit

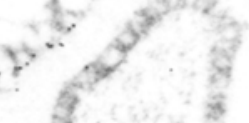

3

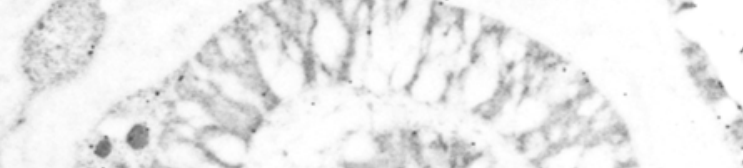

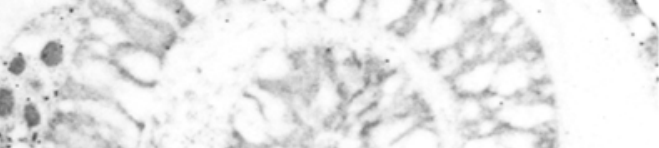

G.

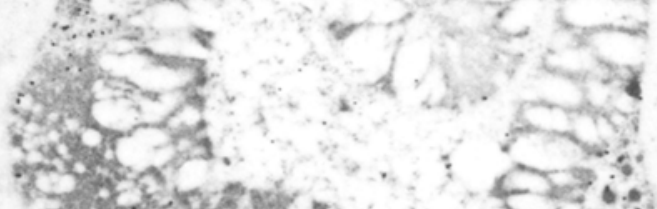

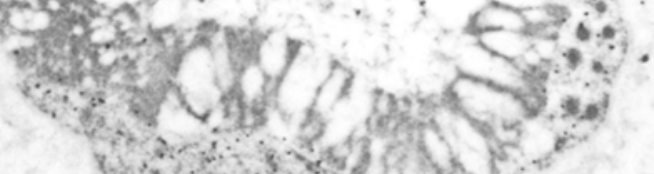

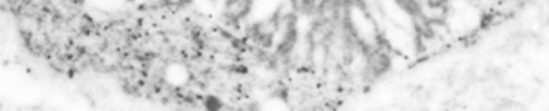

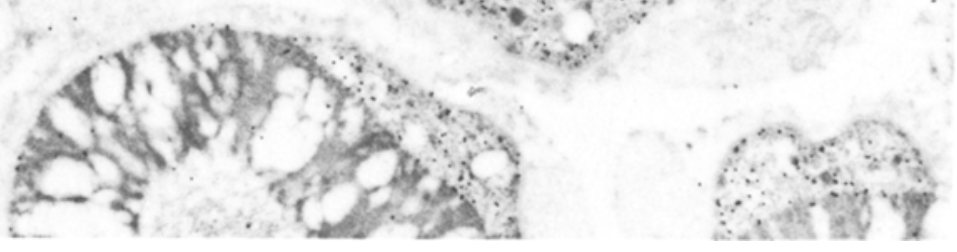



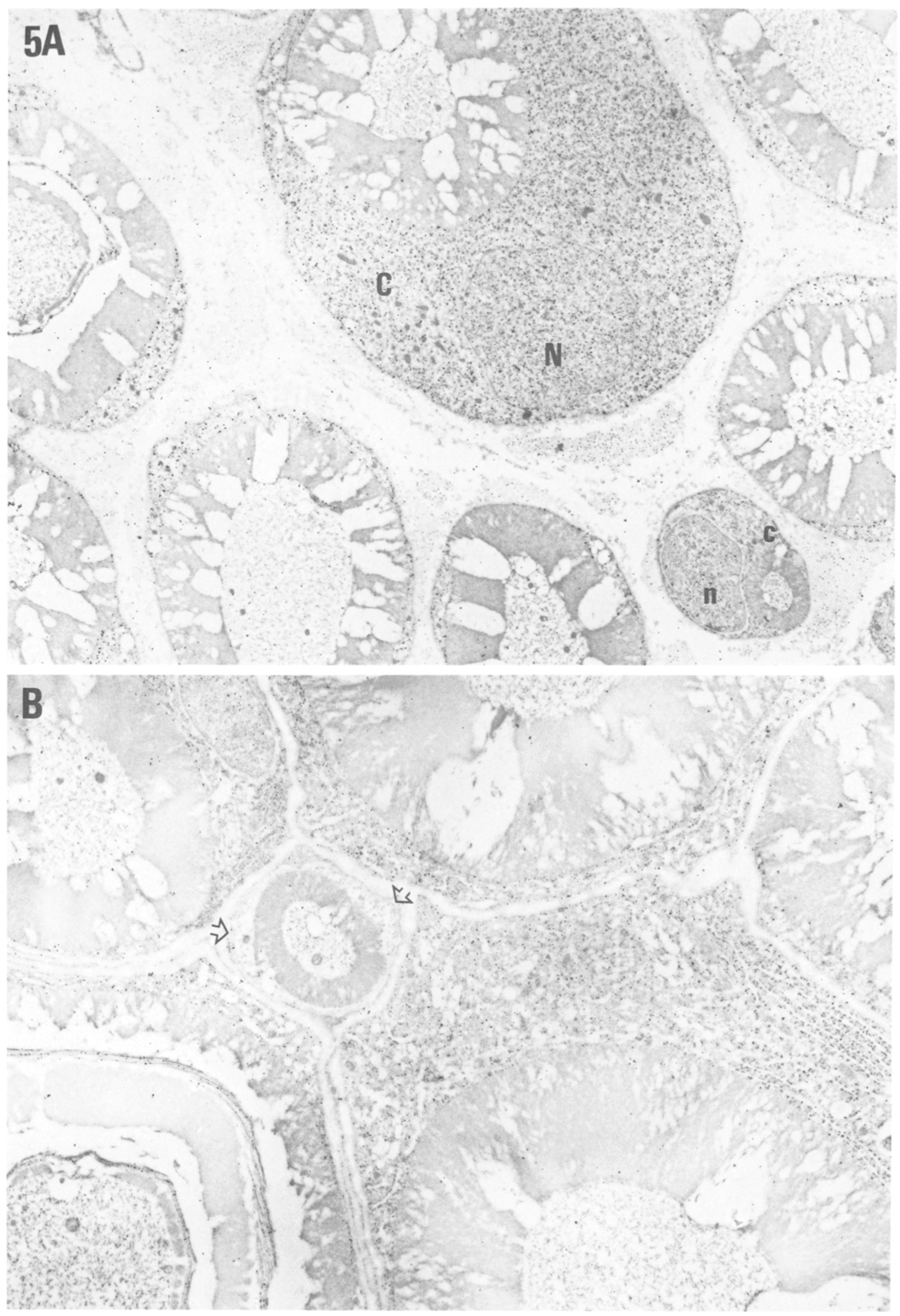
$6 A$

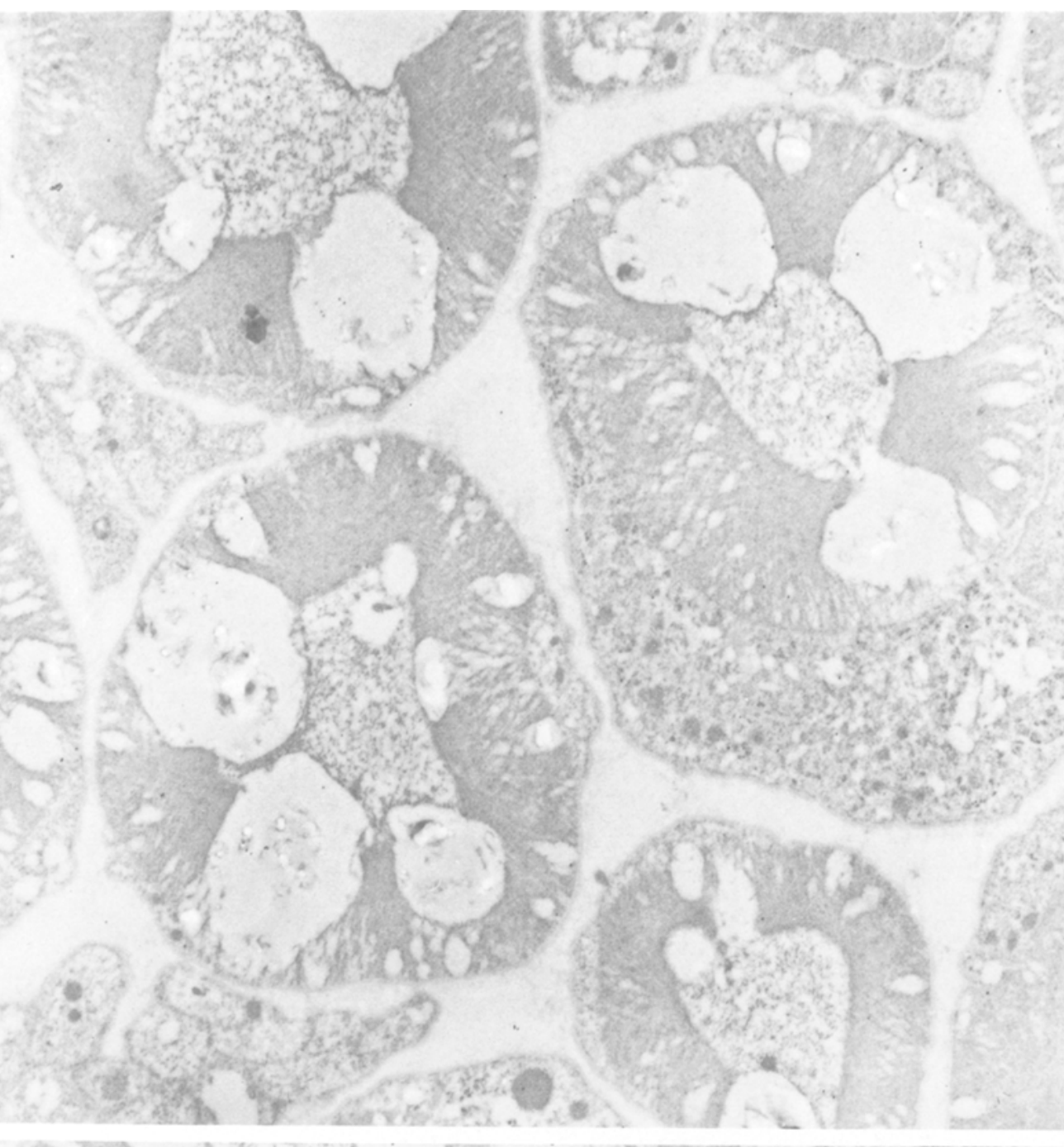

\section{B \\ B 19}

C19

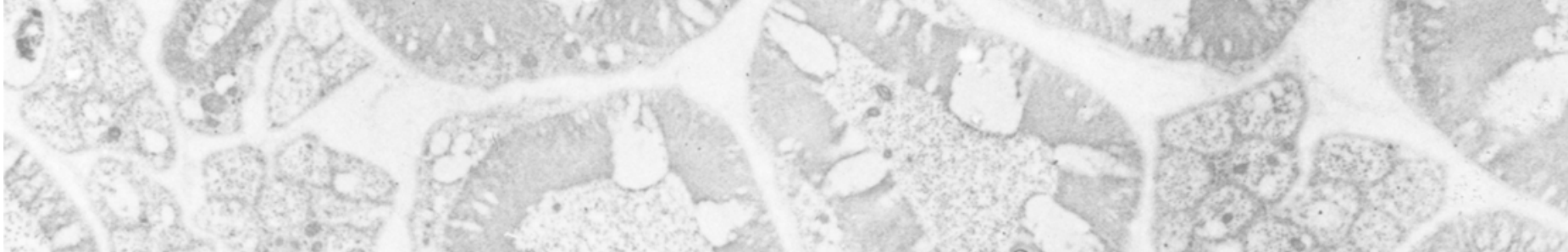

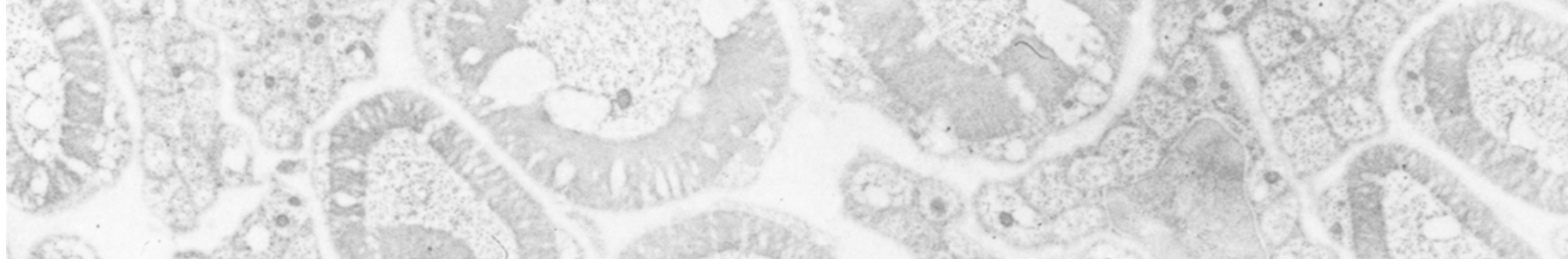

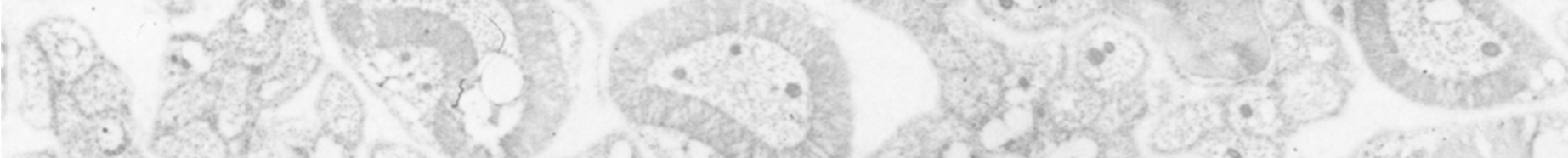

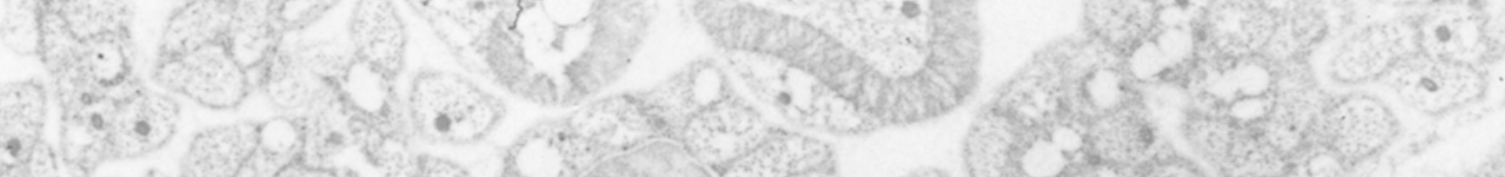

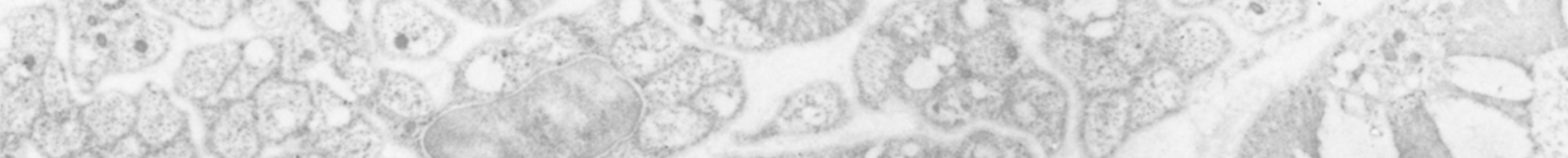

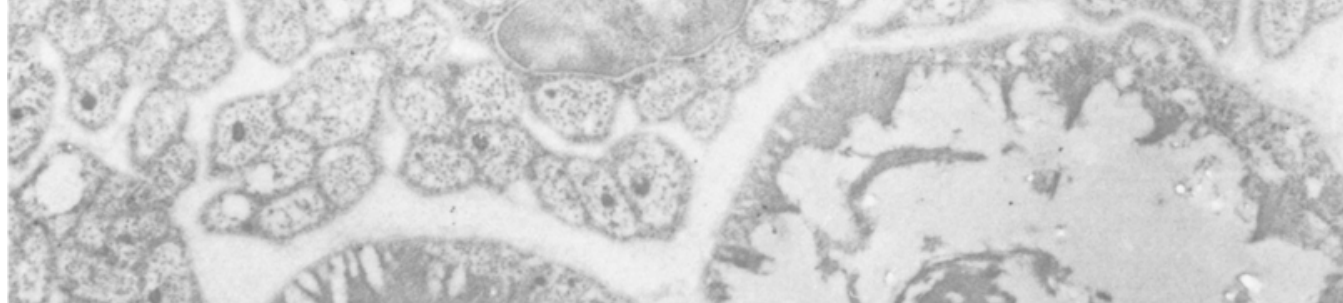




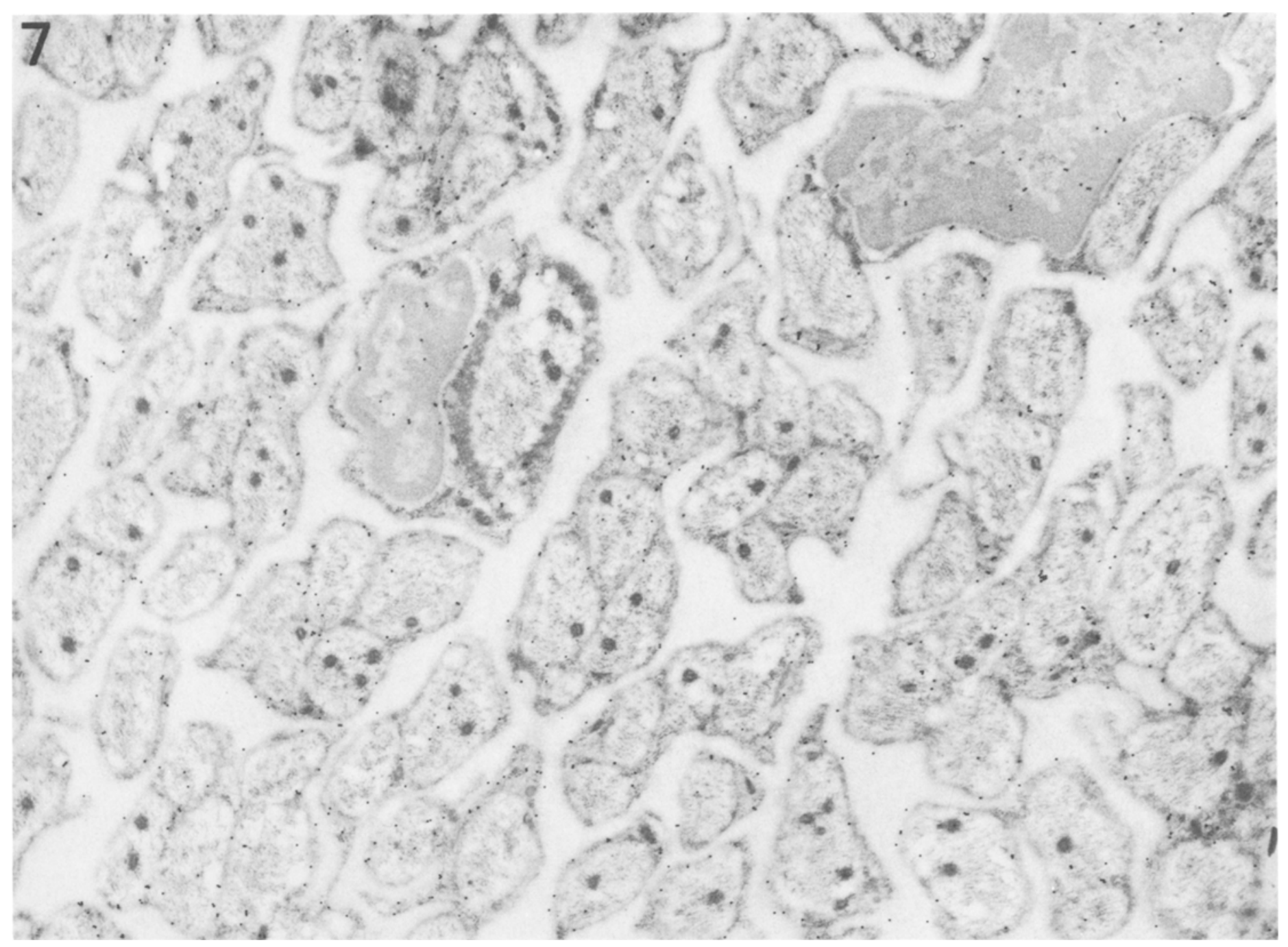

Fig. 7. Cross-section of cervical sympathetic trunk shows unmyelinated and a few very small myelinated fibres with very little S100 immunoreactivity. Primary antibody 1:300. $\times 26000$.

carriers of free fatty acids (Haimoto et al., 1985). The protein might play a similar role in Schwann cells during myelination. An alternative possibility is that the $S 100$ protein may play a role in the reorganization of microtubules in Schwann cells (Donato et al., 1986; Donato, 1987), which might be required for myelination. These two possibilities are not mutually exclusive.

The localization of S100 in the nucleus of Schwann cells is similar to that previously reported in astrocytes in the CNS (Ludwin et al., 1976; Cocchia, 1981) and supports the biochemical co-localization of S100 protein with nuclei isolated from the cerebral cortex (Michetti et al., 1974). A recent report showed no $\$ 100$ immunoreactivity in the nucleus of Schwann cells (Spreca et al., 1989). However, that study utilized pre-embedding immunocy tochemistry on $80 \mu \mathrm{m}$ thick sections. It is possible that the different results are due to difficulty in antibody penetration through the nuclear membrane in that preparation. The current study utilized postembedding immunocytochemistry which allows full access of the antiserum to all regions of the sectioned tissue.

We did not find any consistent evidence of S100b immunoreactivity in axons in the mature, steady-state nervous system. While this does not support an active role for $\$ 100$ as a neurotrophic factor in adult nerve in the steady state (Kligman \& Marshak, 1985; Kligman \& Hsieh, 1987) the potential role of S100 in development or in recovery from injury is not addressed in this study.

In conclusion, our results suggest that Schwann cell expression of $\mathrm{S} 100$ is related to the degree of myelination. We have begun experimental studies to define more clearly the role of $\$ 100$ in development and in recovery following injury. 


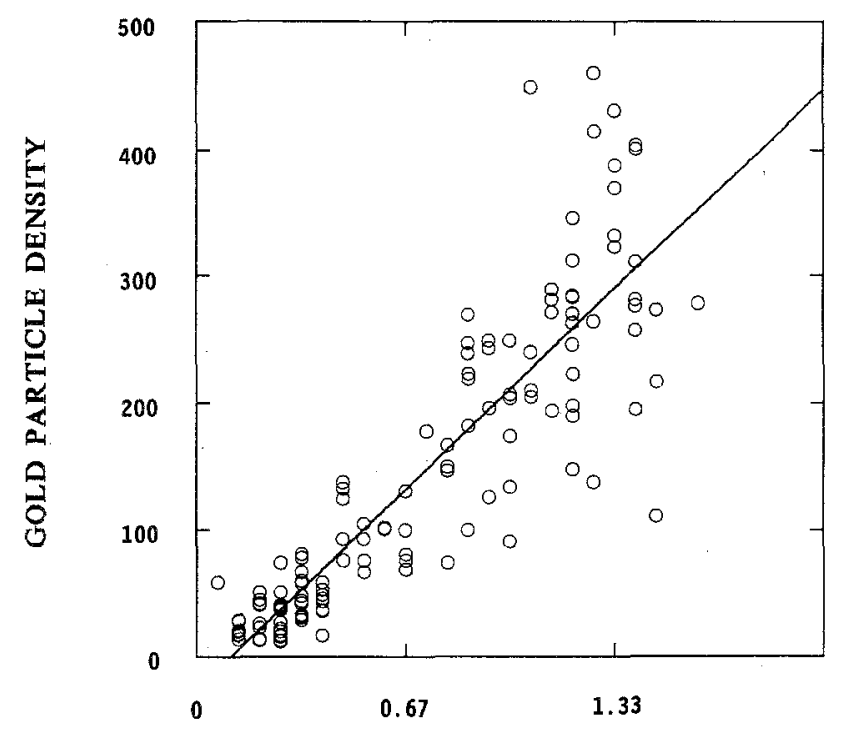

MYELIN THICKNESS

Fig. 8. Density of gold particles (grains per $10^{9} \mu \mathrm{m}^{2}$ ) plotted against myelin thickness $(\mu \mathrm{m})$. Both measurements are taken from photographs as described in the text. The correlation is statistically significant $(R=0.887, P<0.001)$.

\section{Acknowledgements}

We acknowledge the technical assistance of Nancy Kupina in electron microscopy, Mark Ratza in biochemistry, and Elise Gurgevich and Unejoo Jung in photography. We acknowledge the additional assistance of Brenda Johnson and Michael Beaty in counting gold particles. This work was supported by grants from the Juvenile Diabetes Foundation International, the NINDS, and the Veterans Administration.

A preliminary communication of some of these results was presented at meeting of the Society for Neuroscience in October 1989 in Phoenix, Arizona, USA.

\section{References}

BAUDIER, J. (1988) S100 proteins: Structure and calcium binding properties. In Calcium and Calcium Binding Proteins (edited by GERDAY, C., GILLES, R. \& BOLIS, L.) pp. 102-13. Berlin: Springer-Verlag.

BAUDIER, J., BRIVING, C., DEINUM, J., HAGLID, K., SORSKOG, L. \& WALLIN, M. (1982) Effect of S-100 proteins and calmodulin on $\mathrm{Ca}^{2+}$-induced disassembly of brain microtubule proteins in vitro. FEBS Letters 147, $165-7$.

BAUDIER, J. \& COLE, R. D. (1988) Interactions between the microtubule associated proteins and $S 100 \mathrm{~b}$ regulate tau phosphorylation by the $\mathrm{Ca}^{2+} /$ calmodulin dependent protein kinase. Journal of Biological Chemistry 263, 5876-83.

BUNGE, M. B., WILLIAMS, A. K., WOOD, P. H., UITTO, J. \& JEFFREY, J. J. (1980) Comparison of nerve cell and nerve cell plus Schwann cell cultures, with particular emphasis on basal lamina and collagen formation. Journal of Cell Biology 84, 184-202.

COCCHIA, D. (1981) Immunocytochemical localization of S100 protein in the brain of adult rat. Cell and Tissue Research 214, 529-40.

COCCHIA, D. \& MICHETTI, F. (1981) S-100 antigen in satellite cells of the adrenal medulla and the superior cervical ganglion of the rat. An immunochemical and immunocytochemical study. Cell and Tissue Research 215, 103-12.

DONATO, R. (1976) Soluble and membrane-bound S-100 protein in rat cerebral cortex synaptosomes during early postnatal development. Brain Research 109, 649-55.

DONATO, R. (1986) S-100 proteins. Cell Calcium 7, 123-45.

KLIGMAN, D. \& HSIEH, L.-S. (1987) Neurite extension factor induces rapid morphological differentiation of mouse neuroblastoma cells in defined medium. Developmental Brain Research 33, 296-300.

KLIGMAN, D. \& MARSHAK, D. R. (1985) Purification and characterization of a neurite extension factor from bovine brain. Proceedings of the National Academy of Sciences USA $82,7136-9$.

KLIGMAN, D. \& PATEL, J. (1986) A protein modulator stimulates $C$ kinase-dependent phosphorylation of a $90 \mathrm{~K}$ substrate in synaptic membranes. Journal of Neurochemistry 47, 298-303.

LAEMMLI, V. K. (1970) Cleavage of structural proteins during the assembly of the head of bacteriophage T4. Nature 227, 680-5.

LUDWIN, S. K., KOSEK, J. C. \& ENG, L. F. (1976) The topographical distribution of S-100 and GFA proteins in the adult rat brain: An immunohistochemical study using horseradish peroxidase-labelled antibodies. Journal of Comparative Neurology 165, 197-208.

MATUS, A. \& MUGHAL, S. (1975) Immunohistochemical localization of S-100 protein in brain. Nature 258, 746-8.

MICHETTI, F., MIANI, N., DERENZIS, G., CANIGLIA, A. \& CORRER, S. (1974) Nuclear localization of S-100 protein. Journal of Neurochemistry 22, 239-44.

MOORE, B. W. (1965) A soluble protein characteristic of the nervous system. Biochemical and Biophysical Research Communications 6, 739-44.

MoORE, B. W. (1982) Chemistry and biology of the S-100 
protein. Scandinavian Journal of Immunology 15 (Suppl. 9), $53-74$.

SIEGEL, G. J., DESMOND, T. \& ERNST, S. A. (1986) Immunoreactivity and ouabain-dependent phosphorylation of $\left(\mathrm{Na}^{+}+\mathrm{K}^{+}\right)$-adenosine triphosphatase catalytic subunit doublets. Journal of Biological Chemistry 261, 13768-76.

SPRECA, A., RAMBOTTI, M. G., RENDE, M. et al. (1989) Immunocytochemical localization of $S-100 \mathrm{~b}$ protein in degenerating and regenerating rat sciatic nerves. Journal of Histochemistry and Cytochemistry 37, 441-6.

STEFANSSON, K., WOLLMANN, R. L. \& MOORE, B. W. (1982) Distribution of $S-100$ protein outside the central nervous system. Brain Research 234, 309-17.

STEWART, J. A. \& URBAN, I. A. (1972) The postnatal accumulation of S-100 protein in mouse central nervous system. Developmental Biology 29, 372-84.

TOWBIN, H., STAEHELIN, T. \& GORDON, J. (1979) Electrophoretic transfer of proteins from polyacrylamide gels to nitrocellulose sheets: Procedure and some applications. Proceedings of the National Academy of Sciences USA 76, 4350-4.

DONATO, R. (1987) Quantitative analysis of the interaction between S-100 proteins and brain tubulin. Cell Calcium $\mathbf{8}$, 283-97.

DONATO, R. (1988) Calcium-independent, pH-regulated effects of S-100 proteins on assembly-disassembly of brain microtubule protein in vitro. Journal of Biological Chemistry 263, 106-10.

DONATO, R., BATTAGLIA, F. \& COCCHIA, D. (1986) Effects of S-100 proteins on assembly of brain microtubule proteins: Correlation between kinetic and ultrastructural data. Journal of Neurochemistry 47, 350-4.

HAGLID, K., HAMBERGER, A., HANSSON, H.-A., HYDEN, H., PERSSON, L. \& RONNBACK, L. (1974) S100 protein in synapses of the central nervous system. Nature 251, $532-4$.

HAGLID, K. G., HANSSON, H. A. \& RONNBACK, L. (1977) S-100 in the central nervous system of rat, rabbit and guinea pig during postnatal development. Brain Research 123, 331-45.

HAIMOTO, H., KATO, K., SUZUKI, F. \& NAGURA, H. (1985) The ultrastructural changes of S-100 protein localization during lipolysis in adipocytes. American Journal of Pathology 121, 185-91.

HANSSON, H.-A., HYDEN, H. \& RONNBACK, L. (1975) Localization of S100 protein in isolated nerve cells by immunoelectron microscopy. Brain Research 93, 349-52.

HERSCHMAN, H. R., LEVINE, L. \& DEVELLIS, J. (1971) Appearance of a brain-specific antigen (S-100) protein in the developing rat brain. Journal of Neurochemistry 18, 629-33.

HOLTON, B. \& WESTON, J. A. (1982) Analysis of glial cell differentiation in peripheral nervous tissue. I. S100 accumulation in quail embryo ganglion cultures. Developmental Biology 89, 64-71.

HOLTON, B. \& WESTON, J. A. (1988) Analysis of glial cell differentiation in peripheral nervous tissue. II. Neurons promote $S 100$ synthesis by purified glial precursor cell populations. Developmental Biology 89, 72-81.

HYDEN, H. \& RONNBACK, L. (1975) S-100 in isolated neurons and glial cells from rat, rabbit and guinea pig during early postnatal development. Neurobiology 5, 291-302.

ISOBE, T., ISHIOKA, N. \& OKUYAMA, T. (1981) Structural relation of two S-100 proteins in bovine brain; subunit composition of S-100a protein. European Journal of Biochemistry 115, 469-74.

ISOBE, T. \& OKUYAMA, T. (1981) The amino acid sequence of the alpha subunit in bovine brain 5100 a protein. European Journal of Biochemistry 116, 79-86.

ISOBE, T., TAKAHASHI, K. \& OKUYAMA, T. (1984) S-100a (alpha, alpha) protein is present in neurons of the central and peripheral nervous system. Joumal of Neurochemistry 43, 1494-6.

KLIGMAN, D. \& HILT, D. C. (1988) The S100 protein family. Trends in Biochemical Sciences 13, 437-43. 